Article

\title{
Development of a Dunaliella tertiolecta Strain with Increased Zeaxanthin Content Using Random Mutagenesis
}

\author{
Minjae Kim ${ }^{1}$, Junhak Ahn ${ }^{1}$, Hancheol Jeon ${ }^{2}$ and EonSeon Jin ${ }^{1, *}$ \\ 1 Department of Life Science and Research Institute for Natural Sciences, Hanyang University, Seoul 04763, \\ Korea; sciencekor89@gmail.com (M.K.); jkahn11@hanmail.net (J.A.) \\ 2 Department of Genetic Resources Research, National Marine Biodiversity Institute of Korea, Seocheon 33662, \\ Korea; hjeon@mabik.re.kr \\ * Correspondence: esjin@hanyang.ac.kr
}

Academic Editors: Adele Cutignano and Giovanna Romano

Received: 20 February 2017; Accepted: 18 June 2017; Published: 21 June 2017

\begin{abstract}
Zeaxanthin is a xanthophyll pigment that is regarded as one of the best carotenoids for the prevention and treatment of degenerative diseases. In the worldwide natural products market, consumers prefer pigments that have been produced from biological sources. In this study, a Dunaliella tertiolecta strain that has 10-15\% higher cellular zeaxanthin content than the parent strain (zea1), was obtained by random mutagenesis using ethyl methanesulfonate (EMS) as a mutagen. This mutant, $m p 3$, was grown under various salinities and light intensities to optimize culture conditions for zeaxanthin production. The highest cellular zeaxanthin content was observed at $1.5 \mathrm{M} \mathrm{NaCl}$ and $65-85 \mu \mathrm{mol}$ photons $\cdot \mathrm{m}^{-2} \cdot \mathrm{s}^{-1}$, and the highest daily zeaxanthin productivity was observed at $0.6 \mathrm{M}$ $\mathrm{NaCl}$ and $140-160 \mu \mathrm{mol}$ photons $\cdot \mathrm{m}^{-2} \cdot \mathrm{s}^{-1}$. The maximal yield of zeaxanthin from $m p 3$ in fed-batch culture was $8 \mathrm{mg} \cdot \mathrm{L}^{-1}$, which was obtained at $0.6 \mathrm{M} \mathrm{NaCl}$ and $140-160 \mu \mathrm{mol}$ photons $\cdot \mathrm{m}^{-2} \cdot \mathrm{s}^{-1}$. These results suggest that random mutagenesis with EMS is useful for generating $D$. tertiolecta strains with increased zeaxanthin content, and also suggest optimal culture conditions for the enhancement of biomass and zeaxanthin production by the zeaxanthin accumulating mutant strains.
\end{abstract}

Keywords: zeaxanthin; Dunaliella tertiolecta; EMS mutagenesis; salinity; light intensity; repeated fed-batch culture

\section{Introduction}

Zeaxanthin, a xanthophyll member of the carotenoids, is a yellow pigment that is produced by most photosynthetic organisms, including higher plants and many microalgae [1]. Zeaxanthin participates in cellular photo-protection by filtering, quenching, and/or scavenging excessive light energy [2]. Due to the strong antioxidant activity of zeaxanthin, it has been recommended for the prevention of cardiovascular disease, some types of cancer, and, especially, age-related macular degeneration [3,4].

Xanthophyll pigments, including zeaxanthin and lutein, have been used as food additives and food coloring agents, approved by the EU as E161h (zeaxanthin) and E161b (lutein). Market demand for xanthophyll pigments, mostly lutein, exceeds \$250 million per year in the USA [5]. The zeaxanthin market is still young, even though the importance of zeaxanthin for macular healthcare has been consistently reported [4,6]. Despite the recommended daily xanthophyll intake of $6.0 \mathrm{mg}$ [7], the xanthophyll pigment industry has suffered from low productivity. Marigold (Tagetes erecta $\mathrm{L}$.) flower petals, which are the current major conventional source of xanthophylls, contain only ca. $0.03 \%$ $(\mathrm{dw} / \mathrm{dw})$ of xanthophylls [8]; thus, there is a demand for better sources for xanthophyll production. 
Microalgae are emerging as major bio-resources for sustainable pigment production. In particular, some microalgal species have high lutein productivity; these include Chlorella zofingiensis [9], Scenedesmus sp. [10], and Muriellopsis sp. [11]. In earlier reports, zeaxanthin was isolated from two species of green algae [12,13] and a cyanobacterium [14]; these studies have described methods and efficiency of extraction and purification of zeaxanthin from respective wild type strains. The advantages of using microalgae for pigment production include (1) a higher growth rate and higher pigment content (about $1 \%$ of dry weight) in comparison with marigold flower petals and other higher plants, (2) daily harvesting under optimal operating conditions, and (3) a pigment extraction process that is shorter than that for marigold flowers $[15,16]$. However, small cell size, the presence of a rigid cell wall, and low cell density in cultures are hurdles for efficient pigment production. To achieve economically feasible pigment production, high pigment content and biomass productivity should be balanced.

In general, Dunaliella species are used to produce carotenoid pigments because they have two advantages. First, they accumulate carotenoids under high-salinity conditions, and thus do not compete with freshwater microalgae and land plants for potable water supply and arable land. Second, pigment extraction from Dunaliella is easier than that from other microalgae because it lacks a rigid cell wall [17]. The effects of salinity on carotenoid biosynthesis and the maximum density of microalgae were reported previously [18-21]. Cell division of microalgae tends to be increased in low saline conditions. Otherwise, carotenoids tend to be accumulated in high saline conditions. Therefore, determination of suitable saline growth conditions is vital for enhancing carotenoid production in Dunaliella.

The zeaxanthin-accumulating mutant of Dunaliella tertiolecta (zea1) was selected from a mutant library generated by ethyl methanesulfonate (EMS) treatment, and was investigated in terms of its responses to stressful conditions [22-24]. Since then, there have been no further studies regarding its zeaxanthin productivity, or further development or optimization of culture conditions.

In this study, we performed two different methods to achieve enhancement of zeaxanthin production; one was to increase cellular zeaxanthin content, and the other was to increase biomass and growth rate. Thus, we used random mutagenesis to generate mutants with increased zeaxanthin content, and attempted to optimize growing conditions for maximal zeaxanthin production. Several mutants with enhanced zeaxanthin accumulation were generated by EMS treatment, and the mp3 mutant was selected as a promising candidate. We confirmed that salinity of the culture-medium, and light intensity, are crucial factors to control biomass and zeaxanthin content. We determined the optimum salinity of the culture medium, and optimum light conditions for zeaxanthin production, by the $m p 3$ strain. We also confirmed that zeaxanthin yield can be improved by repeated fed-batch cultivation under optimized culture conditions.

\section{Results}

\subsection{Selection and Characterization of the Dunaliella Tertiolecta mp3 Strain}

During the initial visual screening process, approximately 200 candidates were selected from about $8 \times 10^{5}$ colonies obtained by chemical mutagenesis of the zea1 strain with EMS on the basis of their yellowish-green coloration. After pigment profile analysis by HPLC, three mutants (mut6, mut9, and mut12) were selected on the basis of their relative zeaxanthin per chlorophyll $a$ content (Figure S1). These mutants lacked neoxanthin, violaxanthin, and antheraxanthin, but accumulated considerable amounts of zeaxanthin, similar to the parental strain (zea1). From the preliminary results of zeaxanthin content and growth pattern, mut12 had the highest zeaxanthin content and growth, and was therefore used in all further experiments. This mut12 was renamed macular pigment mutant 3 (mp3) according to its pigment profile characteristics.

When grown as colonies on agar at $65-85 \mu \mathrm{mol}$ photons $\cdot \mathrm{m}^{-2} \cdot \mathrm{s}^{-1}, \mathrm{mp} 3$ appeared yellowish-green. The pigment profile was almost the same as that of the parental strain, but the number of chlorophyll molecules in $m p 3$ was greatly decreased (Figure 1); the mp3 mutant had reduced total chlorophyll 
content and higher chlorophyll $a / b$ ratio than zea1, and its autofluorescence signal was slightly decreased compared to zea1 (Figure S2). mp3 grew slower than other strains, and contained 10-15\% more zeaxanthin per cell than zea1 (Figure 2A,B). Zeaxanthin yield of $m p 3$ was about $19 \%$ higher than that of zea1 under the same culture conditions (Figure 2C).
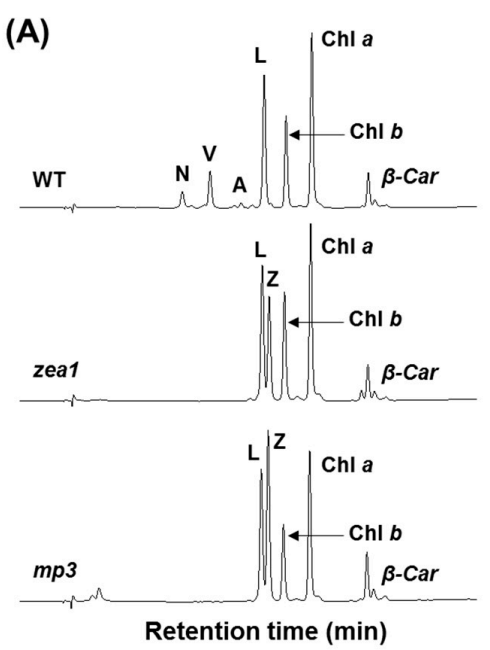

(B)

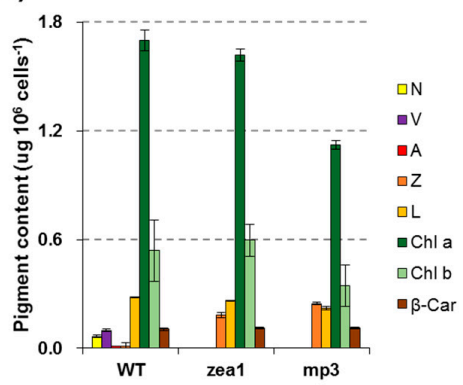

(C)

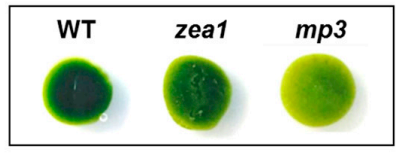

Figure 1. Pigment characteristics of wild type and mutant D. tertiolecta strains. (A) HPLC elution profile of total pigment extracts from the wild type, zea1, and, mp3 mutant; (B) Pigment composition per $10^{6}$ cells $(n=3)$; (C) Colony color at the same cell density. N, neoxanthin; V, violaxanthin; A, antheraxanthin; $\mathrm{Z}$, zeaxanthin; $\mathrm{L}$, lutein; $\mathrm{Chl}$ a, chlorophyll a; $\mathrm{Chl} b$, chlorophyll b; $\beta$-Car, $\beta$-carotene.

(A)

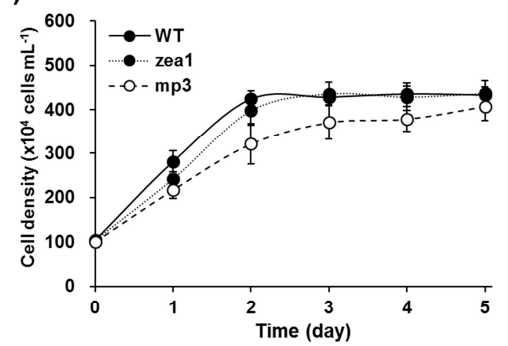

(B)

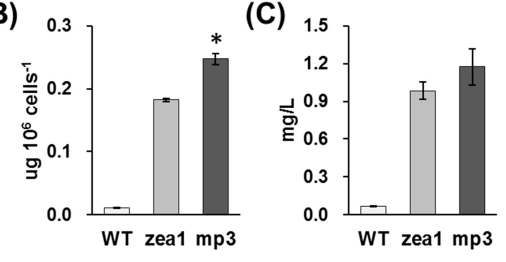

Figure 2. Comparative analysis of D. tertiolecta wild type, zea1, and mp3. (A) Growth patterns of three strains on $1.5 \mathrm{M} \mathrm{NaCl}$ medium; (B) Cellular zeaxanthin content of three strains $\left(\mu \mathrm{g} \cdot 10^{6} \cdot \mathrm{cells}^{-1}\right)$; (C) Zeaxanthin yield of three strains $\left(\mathrm{mg} \cdot \mathrm{L}^{-1}\right)$. Statistical analyses were performed using Student's $t$-test, ${ }^{*} p<0.05$. All experiments were conducted in triplicate.

\subsection{Effect of $\mathrm{NaCl}$ Concentration on Cell Density and Zeaxanthin Yield}

Cell size was similar under different saline conditions; however, cell growth pattern, zeaxanthin content, and biomass were largely affected by salinity of the medium (Figure 3, Table S1). The maximal cell density at $0.3 \mathrm{M} \mathrm{NaCl}$ was similar to that at $0.6 \mathrm{M}$ in the stationary phase (Figure $3 \mathrm{~A}-\mathrm{C}$ ). However, the highest specific growth rate $(\mu)$ of the wild type reached $0.72 \mathrm{~d}^{-1}$ at $0.6 \mathrm{M} \mathrm{NaCl}$; under the same conditions, the specific growth rate of $m p 3$ was $0.46 \mathrm{~d}^{-1}$. Specific growth rates were calculated during the exponential phase for the wild type (days 1-3) and $m p 3$ (days 3-6). Zeaxanthin yield seemed 
to be affected by salinity (Figure 3D). Table 1 shows the carotenoid content per $10^{6}$ cells at different salinities. In the wild type, low salinity-adapted cells tended to have high neoxanthin, violaxanthin, and antheraxanthin contents, but they tended to have low zeaxanthin content. Zeaxanthin content of both zea 1 and $m p 3$ mutants also tended to be reduced with decreasing salinity. The maximal cell density of all strains was observed at both $0.3 \mathrm{M}$ and $0.6 \mathrm{M} \mathrm{NaCl}$, but zeaxanthin content was highest at $3.0 \mathrm{M}$ in the wild type, and at $1.5 \mathrm{M}$ in the zea1 and $m p 3$ mutants. Zeaxanthin yield $\left(\mathrm{mg} \cdot \mathrm{L}^{-1}\right)$ of $m p 3$ was significantly higher than that of zea1 at $0.6 \mathrm{M}$ and $1.5 \mathrm{M} \mathrm{NaCl}$ (Figure 3). Zeaxanthin yield of $m p 3$ was $7 \%, 11 \%$, and $8 \%$ higher than that of zea 1 at $0.3 \mathrm{M}, 0.6 \mathrm{M}$, and $1.5 \mathrm{M} \mathrm{NaCl}$, respectively, but was $14 \%$ lower at $3.0 \mathrm{M} \mathrm{NaCl}$. Because the highest zeaxanthin yield of $m p 3$ occurred in a medium containing $0.6 \mathrm{M} \mathrm{NaCl}$, we considered this medium as optimal for zeaxanthin production (Figure 3D).
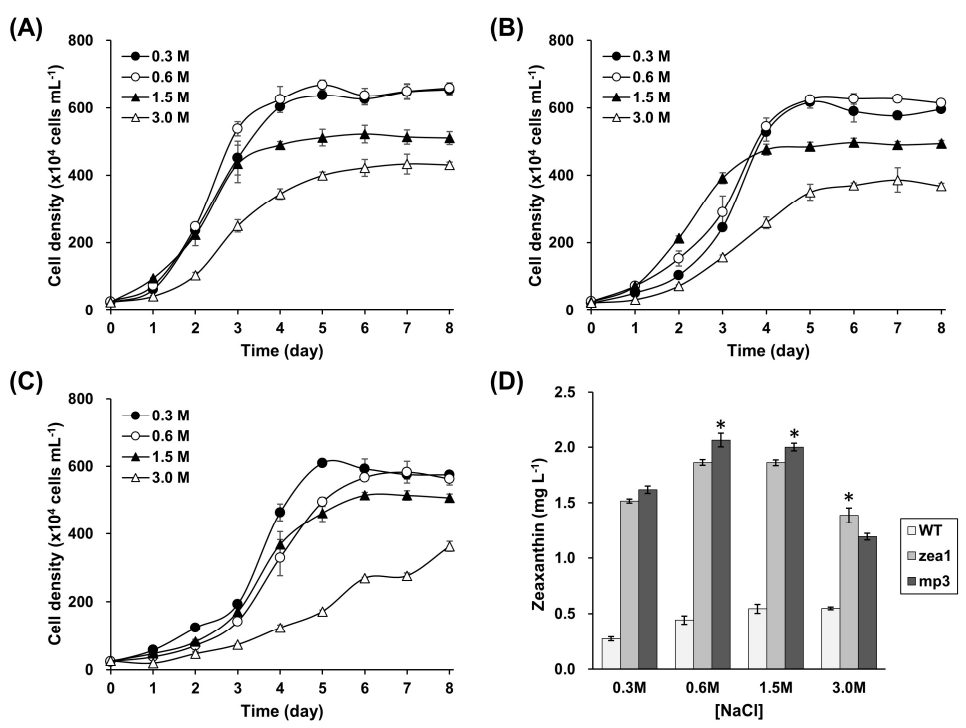

Figure 3. Effects of $\mathrm{NaCl}$ concentration on growth and zeaxanthin production in wild type $D$. tertiolecta, zea1 and, mp3 mutants. Growth pattern of the wild type (A), zea1 (B), and $m p 3$ (C); (D) Zeaxanthin yield of wild type, zea1, and mp3. Dunaliella strains were cultured on media containing $0.3 \mathrm{M}, 0.6 \mathrm{M}, 1.5 \mathrm{M}$, and $3.0 \mathrm{M} \mathrm{NaCl}$, respectively. Statistical analyses were performed using Student's $t$-test, ${ }^{*} p<0.05$. All experiments were conducted in triplicate.

Table 1. Effect of $\mathrm{NaCl}$ concentration on cellular carotenoid content.

\begin{tabular}{|c|c|c|c|c|c|c|c|}
\hline \multirow{2}{*}{ Strains } & \multirow{2}{*}[\mathrm{NaCl}]{} & \multicolumn{6}{|c|}{ Carotenoid Pigments $\left(\mu \mathrm{g} \cdot 10^{6} \cdot\right.$ Cells $\left.^{-1}\right)$} \\
\hline & & Neoxanthin & Violaxanthin & Antheraxanthin & Lutein & Zeaxanthin & $\beta$-Carotene \\
\hline \multirow{4}{*}{$\begin{array}{l}\text { wild } \\
\text { type }\end{array}$} & $0.3 \mathrm{M}$ & $\begin{array}{c}0.112 \\
( \pm 0.008)\end{array}$ & $\begin{array}{c}0.157 \\
( \pm 0.006)\end{array}$ & $0.061( \pm 0.005)$ & $\begin{array}{c}0.507 \\
( \pm 0.022)\end{array}$ & $\begin{array}{c}0.079 \\
( \pm 0.005)\end{array}$ & $\begin{array}{c}0.172 \\
( \pm 0.011)\end{array}$ \\
\hline & $0.6 \mathrm{M}$ & $\begin{array}{c}0.101 \\
( \pm 0.018)\end{array}$ & $\begin{array}{c}0.112 \\
( \pm 0.014)\end{array}$ & $0.061( \pm 0.007)$ & $\begin{array}{c}0.414 \\
( \pm 0.012)\end{array}$ & $\begin{array}{c}0.083 \\
( \pm 0.007)\end{array}$ & $\begin{array}{c}0.133 \\
( \pm 0.013)\end{array}$ \\
\hline & $1.5 \mathrm{M}$ & $\begin{array}{c}0.096 \\
( \pm 0.018)\end{array}$ & $\begin{array}{c}0.074 \\
( \pm 0.005)\end{array}$ & $0.057( \pm 0.003)$ & $\begin{array}{c}0.505 \\
( \pm 0.059)\end{array}$ & $\begin{array}{c}0.117 \\
( \pm 0.013)\end{array}$ & $\begin{array}{c}0.143 \\
( \pm 0.010)\end{array}$ \\
\hline & $3.0 \mathrm{M}$ & $\begin{array}{c}0.122 \\
( \pm 0.010)\end{array}$ & $\begin{array}{c}0.086 \\
( \pm 0.004)\end{array}$ & $0.074( \pm 0.004)$ & $\begin{array}{c}0.433 \\
( \pm 0.027)\end{array}$ & $\begin{array}{c}0.131 \\
( \pm 0.006)\end{array}$ & $\begin{array}{c}0.149 \\
( \pm 0.013)\end{array}$ \\
\hline \multirow{4}{*}{ zea1 } & $0.3 \mathrm{M}$ & N.D. & N.D. & N.D. & $\begin{array}{c}0.358 \\
( \pm 0.017)\end{array}$ & $\begin{array}{c}0.246 \\
( \pm 0.011)\end{array}$ & $\begin{array}{c}0.186 \\
( \pm 0.008)\end{array}$ \\
\hline & $0.6 \mathrm{M}$ & N.D. & N.D. & N.D. & $\begin{array}{c}0.459 \\
( \pm 0.025)\end{array}$ & $\begin{array}{c}0.303 \\
( \pm 0.038)\end{array}$ & $\begin{array}{c}0.184 \\
( \pm 0.004)\end{array}$ \\
\hline & $1.5 \mathrm{M}$ & N.D. & N.D. & N.D. & $\begin{array}{c}0.502 \\
( \pm 0.058)\end{array}$ & $\begin{array}{c}0.374 \\
( \pm 0.012)\end{array}$ & $\begin{array}{c}0.185 \\
( \pm 0.010)\end{array}$ \\
\hline & $3.0 \mathrm{M}$ & N.D. & N.D. & N.D. & $\begin{array}{c}0.402 \\
( \pm 0.025)\end{array}$ & $\begin{array}{c}0.359 \\
( \pm 0.038)\end{array}$ & $\begin{array}{c}0.167 \\
( \pm 0.010)\end{array}$ \\
\hline
\end{tabular}


Table 1. Cont.

\begin{tabular}{|c|c|c|c|c|c|c|c|}
\hline \multirow{2}{*}{ Strains } & \multirow{2}{*}[\mathrm{NaCl}]{} & \multicolumn{6}{|c|}{ Carotenoid Pigments $\left(\mu \mathrm{g} \cdot 10^{6} \cdot\right.$ Cells $\left.^{-1}\right)$} \\
\hline & & Neoxanthin & Violaxanthin & Antheraxanthin & Lutein & Zeaxanthin & $\beta$-Carotene \\
\hline \multirow{4}{*}{ mp3 } & $0.3 \mathrm{M}$ & N.D. & N.D. & N.D. & $\begin{array}{c}0.272 \\
( \pm 0.014)\end{array}$ & $\begin{array}{c}0.262 \\
( \pm 0.019)\end{array}$ & $\begin{array}{c}0.130 \\
( \pm 0.001)\end{array}$ \\
\hline & $0.6 \mathrm{M}$ & N.D. & N.D. & N.D. & $\begin{array}{c}0.329 \\
( \pm 0.016)\end{array}$ & $\begin{array}{c}0.368 \\
( \pm 0.013)\end{array}$ & $\begin{array}{c}0.171 \\
( \pm 0.015)\end{array}$ \\
\hline & $1.5 \mathrm{M}$ & N.D. & N.D. & N.D. & $\begin{array}{c}0.346 \\
( \pm 0.035)\end{array}$ & $\begin{array}{c}0.389 \\
( \pm 0.012)\end{array}$ & $\begin{array}{c}0.173 \\
( \pm 0.008)\end{array}$ \\
\hline & $3.0 \mathrm{M}$ & N.D. & N.D. & N.D. & $\begin{array}{c}0.268 \\
( \pm 0.024)\end{array}$ & $\begin{array}{c}0.312 \\
( \pm 0.029)\end{array}$ & $\begin{array}{c}0.133 \\
( \pm 0.013)\end{array}$ \\
\hline
\end{tabular}

* Note: N.D. means "peak was not detected".

\subsection{Effect of Light Intensity on Growth Rate and Zeaxanthin Productivity}

Cell growth and zeaxanthin content in the wild type, and zea1 and mp3 mutants, were measured under three different light conditions. Increased irradiation promoted cell division in the wild type, zea1, and $m p 3$ (Figure 4). Interestingly, the growth rate of $m p 3$ was dramatically changed by light intensity (Table S2), increasing significantly from that at mid-light conditions. When the mp3 mutant was grown under low-light conditions $\left(65-85 \mu \mathrm{mol}\right.$ photons $\left.\cdot \mathrm{m}^{-2} \cdot \mathrm{s}^{-1}\right)$, its specific growth rate was only $0.46 \mathrm{~d}^{-1}$; however, it increased to $1.18 \mathrm{~d}^{-1}$ under mid-light conditions $\left(140-160 \mu \mathrm{mol}\right.$ photons $\left.\cdot \mathrm{m}^{-2} \cdot \mathrm{s}^{-1}\right)$. Much stronger light (580-620 $\mu$ mol photons) did not further affect the growth rate of $m p 3\left(1.21 \mathrm{~d}^{-1}\right)$. This pattern was also observed in the wild type and zea1, as strong light did not affect the growth rate $\left(0.97 \mathrm{~d}^{-1}\right.$ and $1.11 \mathrm{~d}^{-1}$, respectively) in comparison with mid-light conditions. Specific growth rates were calculated during the same periods of the exponential phase for the wild type, zea1, and $m p 3$. Carotenoid content is presented in Table 2. Dunaliella strains, investigated in this study, tended to have high pigment content under low-light conditions. However, zeaxanthin yield $\left(\mathrm{mg} \cdot \mathrm{L}^{-1}\right)$ of the $m p 3$ and zea1 strains under low- and mid-light conditions was higher than that under high-light conditions. Interestingly, $m p 3$ had a $42 \%$ higher zeaxanthin yield than zea1 under high-light conditions (Figure 4D). Daily zeaxanthin productivity of $m p 3$ was $0.271-0.400 \mathrm{mg} \cdot \mathrm{L}^{-1}$, which was $3-4$ times higher than the productivity of the wild type under all light conditions.
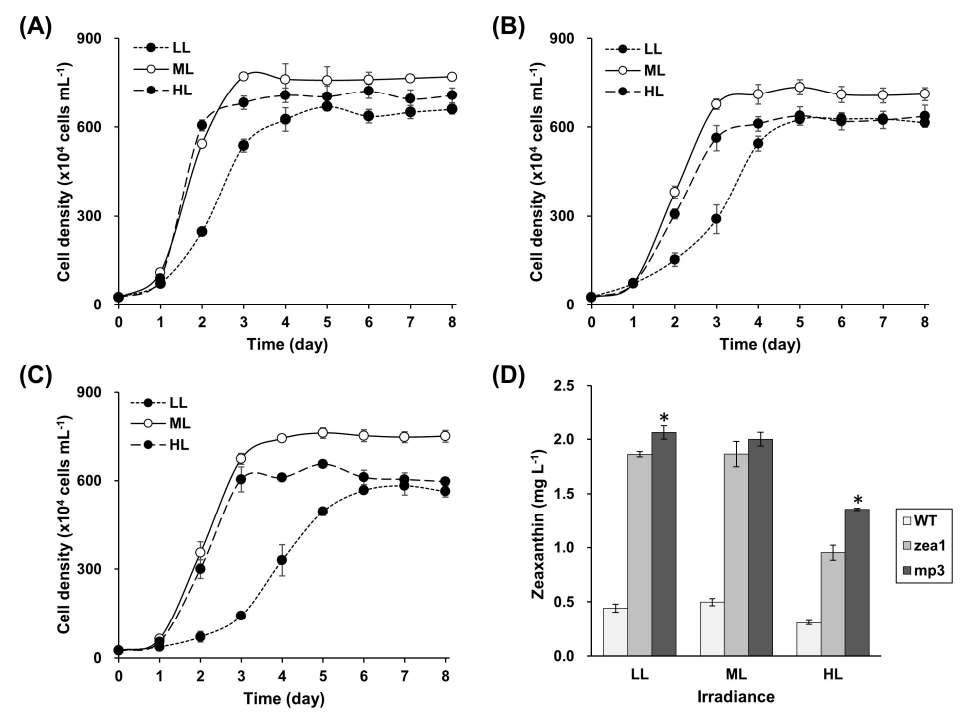

Figure 4. Effects of light intensity on growth and zeaxanthin production in wild type D. tertiolecta, and zea1 and mp3 mutants. Experimental light conditions were low-light (LL), mid-light (ML), and high-light (HL). Growth patterns of wild type (A), zea1 (B), and mp3 (C); (D) Zeaxanthin yield of wild type, zea1, and mp3. Dunaliella strains were cultured on media containing $0.6 \mathrm{M} \mathrm{NaCl}$. Statistical analyses were performed using Student's $t$-test, ${ }^{*} p<0.05$. All experiments were conducted in more than triplicate. 
Table 2. Effect of light intensity on cellular carotenoid content.

\begin{tabular}{|c|c|c|c|c|c|c|c|}
\hline \multirow{2}{*}{ Strains } & \multirow{2}{*}{ Irradiance } & \multicolumn{6}{|c|}{ Carotenoid Pigments $\left(\mu \mathrm{g} \cdot 10^{6} \cdot\right.$ Cells $\left.^{-1}\right)$} \\
\hline & & Neoxanthin & Violaxanthin & Antheraxanthin & Lutein & Zeaxanthin & $\beta$-Carotene \\
\hline \multirow{3}{*}{ wild type } & Low-light & $\begin{array}{c}0.101 \\
( \pm 0.018)\end{array}$ & $\begin{array}{c}0.112 \\
( \pm 0.014)\end{array}$ & $\begin{array}{c}0.061 \\
( \pm 0.007)\end{array}$ & $\begin{array}{c}0.414 \\
( \pm 0.012)\end{array}$ & $\begin{array}{c}0.083 \\
( \pm 0.007)\end{array}$ & $\begin{array}{c}0.133 \\
( \pm 0.013)\end{array}$ \\
\hline & Mid-light & $\begin{array}{c}0.069 \\
( \pm 0.005)\end{array}$ & $\begin{array}{c}0.091 \\
( \pm 0.003)\end{array}$ & $\begin{array}{c}0.056 \\
( \pm 0.004)\end{array}$ & $\begin{array}{c}0.324 \\
( \pm 0.023)\end{array}$ & $\begin{array}{c}0.066 \\
( \pm 0.006)\end{array}$ & $\begin{array}{c}0.119 \\
( \pm 0.006)\end{array}$ \\
\hline & High-light & $\begin{array}{c}0.051 \\
( \pm 0.002) \\
\end{array}$ & $\begin{array}{c}0.072 \\
( \pm 0.004) \\
\end{array}$ & $\begin{array}{c}0.041 \\
( \pm 0.002) \\
\end{array}$ & $\begin{array}{c}0.194 \\
( \pm 0.016) \\
\end{array}$ & $\begin{array}{c}0.043 \\
( \pm 0.001) \\
\end{array}$ & $\begin{array}{c}0.088 \\
( \pm 0.003) \\
\end{array}$ \\
\hline \multirow{3}{*}{$z e a 1$} & Low-light & N.D. & N.D. & N.D. & $\begin{array}{c}0.459 \\
( \pm 0.025)\end{array}$ & $\begin{array}{c}0.303 \\
( \pm 0.038)\end{array}$ & $\begin{array}{c}0.184 \\
( \pm 0.004)\end{array}$ \\
\hline & Mid-light & N.D. & N.D. & N.D. & $\begin{array}{c}0.336 \\
( \pm 0.016)\end{array}$ & $\begin{array}{c}0.253 \\
( \pm 0.012)\end{array}$ & $\begin{array}{c}0.159 \\
( \pm 0.013)\end{array}$ \\
\hline & High-light & N.D. & N.D. & N.D. & $\begin{array}{c}0.236 \\
( \pm 0.006)\end{array}$ & $\begin{array}{c}0.149 \\
( \pm 0.004)\end{array}$ & $\begin{array}{c}0.079 \\
( \pm 0.003)\end{array}$ \\
\hline \multirow{3}{*}{$m p 3$} & Low-light & N.D. & N.D. & N.D. & $\begin{array}{c}0.329 \\
( \pm 0.016)\end{array}$ & $\begin{array}{c}0.368 \\
( \pm 0.013)\end{array}$ & $\begin{array}{c}0.171 \\
( \pm 0.015)\end{array}$ \\
\hline & Mid-light & N.D. & N.D. & N.D. & $\begin{array}{c}0.240 \\
( \pm 0.003)\end{array}$ & $\begin{array}{c}0.267 \\
( \pm 0.005)\end{array}$ & $\begin{array}{c}0.174 \\
( \pm 0.023)\end{array}$ \\
\hline & High-light & N.D. & N.D. & N.D. & $\begin{array}{c}0.173 \\
( \pm 0.005)\end{array}$ & $\begin{array}{c}0.209 \\
( \pm 0.002)\end{array}$ & $\begin{array}{c}0.080 \\
( \pm 0.014)\end{array}$ \\
\hline
\end{tabular}

* Note: N.D. means "peak was not detected".

\subsection{Zeaxanthin Yield in Two Different Batch Culture Systems}

To improve the yield of zeaxanthin and to determine its maximal yield, repeated fed-batch cultivation was performed in a $200 \mathrm{~mL}$ flask-culture system. Maximum zeaxanthin concentrations in repeated fed-batch cultures of $m p 3$ and zea 1 were 3.7 times and 3.4 times those in single-batch cultures, respectively (Figure 5B). This could be the result of the higher cell density observed in fed-batch cultures (Figure 5A). In detail, the maximum zeaxanthin yield of $m p 3$ was $8 \mathrm{mg} \cdot \mathrm{L}^{-1}$, which was about $20 \%$ higher than that of zea1 $\left(6.5 \mathrm{mg} \cdot \mathrm{L}^{-1}\right)$. For a better comparison of zeaxanthin concentration between the two culture systems for the $m p 3$ strain, the amount of pigment per $10^{6}$ cells was calculated. Data analysis was performed with samples that had the highest zeaxanthin content during the experiment period. In fed-batch culture, it was $0.365 \mu \mathrm{g}$ at 11 days after inoculation, which was about $15 \%$ higher than the content in single-batch culture $(0.318 \mu \mathrm{g}$ at 9 days), indicating that repeated fed-batch cultures may increase zeaxanthin yield and accumulation.
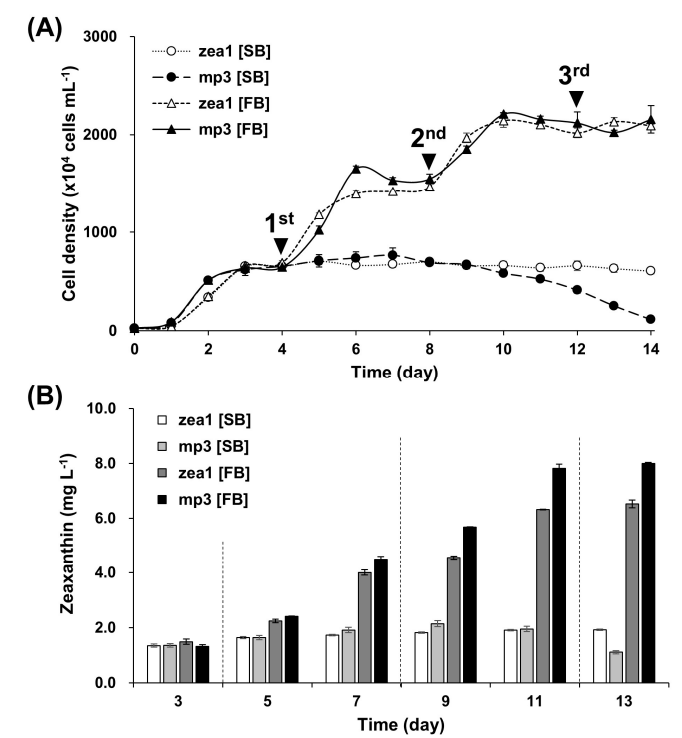

Figure 5. Comparison between single-batch (SB) and repeated fed-batch (FB) culture systems. Total replacement of the culture medium was conducted three times; on day 4 (1st), day 8 (2nd), and day 12 (3rd). (A) Growth patterns of zea1 and mp3. Growth was improved at the previous two points but did not increase by more than $2500 \times 10^{4}$ cells $\cdot \mathrm{mL}^{-1}$; (B) Zeaxanthin yield of zea1 and $m p 3$ according to two culture systems. The culture conditions are presented in detail in materials and methods. 


\section{Discussion}

Zeaxanthin has great potential as an antioxidant and is useful for macular healthcare. It is converted to antheraxanthin by zeaxanthin epoxidase in the xanthophyll cycle [25]. Hence, zeaxanthin is not accumulated in the cell to levels suitable for commercialization, except under stress. The use of genetically modified organisms (GMOs), which are generated by transformation to insert heterologous genes, for food applications is strictly regulated in the EU, the USA, and in the majority of other countries in the world [26]. Therefore, we developed a non-GMO strain and identified its optimal culture conditions to enhance zeaxanthin production. Our EMS mutant, mp3, accumulates zeaxanthin to higher levels (by 10-15\% on per-cell basis) than the well-known mutant zea1 (Figure 2B).

Random mutagenesis with chemical agents is probably the simplest method to genetically improve industrial microalgae. EMS is an alkylating agent that induces random mutations in genomes by nucleotide substitution, especially by guanine alkylation. This agent forms nucleotide adducts, causing them to form mispairs with their complementary bases $[27,28]$. Chemical mutagenesis is classified as a non-GMO method because it does not require the insertion of heterologous genes or vectors [29]. Including the D. tertiolecta zea1 mutant, there have been many reports of EMS mutants with increased biomass and improved productivity of high-value products [30-33]. Although this is a powerful method for obtaining improved mutant lines, it is difficult to identify the mutations responsible for the mutant phenotypes. Only in a few random mutants have the mutated pathways related to phenotypes been suggested [22].

The mp3 mutant had notable changes in physiological features. One of them is color. When we inoculated cells on solid culture plates at the same density, the $m p 3$ colonies were bright yellowish-green. The pale-color phenotype has been reported for several truncated antenna mutants, which have lower total chlorophyll content, higher chlorophyll $a / b$ ratio, and a lower growth rate than the wild type under low-light conditions. There are several reports emphasizing the advantages of smaller-sized chlorophyll antenna mutants. The truncated, light-harvesting antennae are photosynthetically more productive under high-light and high-density culture conditions than cultures with fully pigmented cells. This improvement is due to alleviation of over-absorption, and dissipation of excess energy by the outer layer of cells in the culture, resulting in improved light penetration deeper into the culture and culture productivity $[34,35]$. Our results showed that $m p 3$ could be considered as an antenna mutant. $m p 3$ had reduced total chlorophyll content and a higher chlorophyll $a / b$ ratio than the parental strain, zea1. Also, the specific growth rate of $m p 3$ was lower than that of the wild type and zea1 under low-light conditions, but the specific growth rate of $m p 3$ was higher than those of wild type and zea1 under mid- and high-light conditions (Table S2). In addition, our data showed that mp3 has higher zeaxanthin productivity than zea1 in high-light conditions (Figure S3). These results suggest that the $m p 3$ mutant could be more productive than the parental zea1 strain under high-light conditions and higher cell density conditions. Although the mp3 mutant has several significant phenotypes of antenna mutants, it is difficult to elucidate the exact genotype of EMS random mutants without whole-genome sequencing.

Manipulation of the $\beta$-carotene branches of the carotenogenic pathway, such as lycopene cyclase $\beta(L C Y B)$ and $\beta$-carotene hydroxylase $(C H Y B)$, could enhance the production of zeaxanthin precursors. The mutation in mp3 may have affected these genes to enhance the production of zeaxanthin. In fact, overexpression of Crocus sativus LcyB in Arabidopsis thaliana resulted in accumulation of $\beta$-carotene and lutein [36], and overexpression of $A$. thaliana ChyB in $A$. thaliana resulted in accumulation of zeaxanthin [37]. Recently, a strategy has been reported to increase zeaxanthin content in Chlamydomonas reinhardtii by knocking out genes that encode the components of the carotenoid pathway $(Z E P)$ and the signal molecules for antenna assembly (Fts Y) [38]. This strategy uses the RNP-mediated CRISPR/CAS9 system, which is considered a non-GMO methodology. If the exact genotype of $m p 3$ is identified, this gene can be edited to increase zeaxanthin content in other microalgae.

Generally, large biomass and high growth rate are required to obtain high productivity; thus, there have been many attempts to enhance productivity by optimizing culture conditions [39]. There 
are several key factors in growth regulation, including salinity, temperature, $\mathrm{pH}$, carbon source, and nutrients. Salinity is one of the most important environmental factors that affect physiological and biochemical responses in microalgae [40]. A number of studies have shown that the highest $\beta$-carotene content in Dunaliella salina is achieved under high-salinity conditions [19], and the increase in salinity increases cellular carotenoid content in wild type D. tertiolecta [18]. In our study, zeaxanthin tended to accumulate proportionally to a salinity increase in wild type D. tertiolecta. However, our results show that extremely high-salinity conditions are not optimal for increasing zeaxanthin production. On the basis of our results, we chose $0.6 \mathrm{M} \mathrm{NaCl}$ as the optimal salinity of the culture medium, which is similar to that of natural seawater $(0.581 \mathrm{M})$; cultivation costs using natural seawater could be lower than those with artificial seawater. Also, the use of natural seawater could avoid competition with industries that use fresh water.

Although the maximal biomass of mp3 was highest in $0.6 \mathrm{M} \mathrm{NaCl}$ media, additional optimization of environmental factors was necessary to increase its relatively low growth rate, thus, we varied light intensity. Light is an essential environmental factor for photosynthetic organisms. Adequate light energy is good for microalgal growth, but excessive energy has negative effects on the cell. Thus, excessive energy is dissipated as heat through a photoprotective mechanism-non-photochemical quenching [41]. In terms of the relationship between input (cost) and output (productivity), irradiation with excessive light would be wasteful. For this reason, there are many reports on optimization of light intensity to achieve the best conditions for microalgal growth rate. In most microalgae, photosynthesis becomes saturated at about $30 \%$ of total solar energy (1700 to $2000 \mu \mathrm{mol}$ photons $\cdot \mathrm{m}^{-2} \cdot \mathrm{s}^{-1}$ ), and some picoplankton species grow at optimal rates at $50 \mu \mathrm{mol}$ photons $\cdot \mathrm{m}^{-2} \cdot \mathrm{s}^{-1}$, and are photo-inhibited at $130 \mu \mathrm{mol}$ photons $\cdot \mathrm{m}^{-2} \cdot \mathrm{s}^{-1}$ (reviewed in [42]). Tang et al. [43] reported that the growth rate of $D$. tertiolecta was increased with increasing light intensities from $100 \mu \mathrm{mol}$ photons $\cdot \mathrm{m}^{-2} \cdot \mathrm{s}^{-1}$ to $350 \mu \mathrm{mol}$ photons $\cdot \mathrm{m}^{-2} \cdot \mathrm{s}^{-1}$. Our results show a similar pattern: the growth rates of wild type, zea1, and mp3 increased sharply with an increase in light intensity, and saturated at $>140 \mu \mathrm{mol}$ photons $\cdot \mathrm{m}^{-2} \cdot \mathrm{s}^{-1}$. We chose mid-light intensity $\left(140-160 \mu \mathrm{mol}\right.$ photons $\left.\cdot \mathrm{m}^{-2} \cdot \mathrm{s}^{-1}\right)$ as the optimal light condition because excessive light energy induces cell damage and increases the cost of microalgal cultivation. Daily zeaxanthin productivity should be considered in the context of reducing cultivation cost. Thus, the zeaxanthin productivity $\left(\mathrm{mg} \cdot \mathrm{L}^{-1} \cdot \mathrm{d}^{-1}\right)$ of $m p 3$ was calculated during the culturing period; low-light (7 days), mid-light (5 days), and high-light conditions (5 days) (Figure S3). Due to the reduced cultivation period, the daily zeaxanthin productivity of $m p 3$ under mid-light conditions was $0.400 \mathrm{mg} \cdot \mathrm{L}^{-1}$, which was $36 \%$ higher than under the low-light conditions $\left(0.295 \mathrm{mg} \cdot \mathrm{L}^{-1}\right)$. The daily productivity of the zea1 mutant was also higher (by $20 \%$ ) under mid-light conditions $\left(0.373 \mathrm{mg} \cdot \mathrm{L}^{-1}\right)$ than under low-light conditions $\left(0.310 \mathrm{mg} \cdot \mathrm{L}^{-1}\right)$. Thus, our results indicate that mid-light conditions are optimal for increasing zeaxanthin productivity.

In industry, a fed-batch cultivation method has been used extensively because of its diverse advantages [44]. One is the reduction of time needed to reach the stationary phase, which is the optimal time-point for compound production. The other is that it is easy to maintain the optimal nutrient composition of culture media and to regulate the cultivation process. Some reports have described the details of fed-batch cultivation for the production of valuable compounds [45-47]. Through simulation of the fed-batch cultivation process at the flask scale, we determined that the maximal zeaxanthin yield of the mp3 mutant under optimized salinity and light conditions was $8 \mathrm{mg} \cdot \mathrm{L}^{-1}$.

There have been many reports of zeaxanthin content in photosynthetic organisms, such as corn (Zea mays L.), wolfberry (Lycium chinense), marigold flower, and several Chlorophycean microalgae [8,48-50]. Among higher plants, zeaxanthin content is $0.0057 \mathrm{mg} \cdot \mathrm{g}^{-1}$ in dried yellow dent corn, and $1 \mathrm{mg} \cdot \mathrm{g}^{-1}$ (as zeaxanthin dipalmitate) in wolfberry. Marigold flowers, a well-known lutein source, contain only $5 \%$ of the total carotenoids of zeaxanthin $\left(0.025 \mathrm{mg} \cdot \mathrm{g}^{-1}\right)$. Among freshwater microalgae, zeaxanthin content is $1 \mathrm{mg} \cdot \mathrm{g}^{-1}$ in Monoraphidium braunii, $0.71 \mathrm{mg} \cdot \mathrm{g}^{-1} \mathrm{in}$ Chlorella fusca, and $0.46 \mathrm{mg} \cdot \mathrm{g}^{-1}$ in Scenedesmus vacuolatus. Among genetically modified plants and algae, $0.04 \mathrm{mg} \cdot \mathrm{g}^{-1}$ 
of zeaxanthin was reported in potato (Solanum tuberosum L.), and $2.4 \mathrm{mg} \cdot \mathrm{g}^{-1}$ in Chlamydomonas reinhardtii $[22,38,51]$. In comparison with the above data, $6.6-7.0 \mathrm{mg} \cdot \mathrm{g}^{-1}$ of zeaxanthin in the $m p 3$ mutant is a quite high level. Thus, this mutant has the potential to replace the present resources used for zeaxanthin production. Before commercialization, its zeaxanthin yield should be confirmed at an industrial scale, such as in a closed photo-bioreactor or an open raceway pond, because multiple variable factors may affect productivity in these settings. Thus, future studies should aim to determine the pattern of zeaxanthin production by zeaxanthin-accumulating mutants (zea1, $m p 3)$ during industrial-scale cultivation.

\section{Materials and Methods}

\subsection{Strains and Culture Conditions}

Wild type Dunaliella was isolated by Mordhay Avron [52] and was formerly named Dunaliella salina, but recent molecular phylogenetic characterization showed that it is very similar to Dunaliella tertiolecta [53]. Using genomic analysis, we confirmed the genomic similarity and renamed it $D$. tertiolecta. The zea1 mutant strain, which cannot synthesize any $\beta, \beta$-epoxycarotenoids derived from zeaxanthin, was described previously [22]. It constitutively accumulates zeaxanthin, but lacks antheraxanthin, violaxanthin, and neoxanthin under all growth conditions.

The standard culture mode was a single-batch culture system with no additions or withdrawals during incubation. The growth medium was a slightly modified version of artificial saline water used by Pick et al. [54] and contained the following ingredients: $40 \mathrm{mM}$ Tris- $\mathrm{HCl}$ (pH 7.4), $5 \mathrm{mM}$ $\mathrm{KNO}_{3}, 4.5 \mathrm{mM} \mathrm{MgCl} 2,0.5 \mathrm{mM} \mathrm{MgSO}_{4}, 0.3 \mathrm{mM} \mathrm{CaCl}_{2}, 0.1 \mathrm{mM} \mathrm{K}_{2} \mathrm{HPO}_{4}, 2 \mu \mathrm{M} \mathrm{FeCl}_{3}, 20 \mu \mathrm{M}$ Na-EDTA, $50 \mu \mathrm{M} \mathrm{H}_{3} \mathrm{BO}_{3}, 10 \mu \mathrm{M} \mathrm{MnCl}_{2}, 0.8 \mu \mathrm{M} \mathrm{ZnSO}_{4}, 0.4 \mu \mathrm{M} \mathrm{CuSO}_{4}, 2 \mu \mathrm{M} \mathrm{Na}_{2} \mathrm{MoO}_{4}, 1.5 \mu \mathrm{M} \mathrm{NaVO}_{3}$, $0.2 \mu \mathrm{M} \mathrm{CoCl}_{2}$, and $25 \mathrm{mM} \mathrm{NaHCO}_{3}$ as an inorganic carbon source. Both D. tertiolecta wild type and zea1 were grown photoautotrophically, in $500 \mathrm{~mL}$ flasks, under $65-85 \mu \mathrm{mol}$ photons $\cdot \mathrm{m}^{-2} \cdot \mathrm{s}^{-1}$ of continuous white fluorescent light, at $25 \pm 1{ }^{\circ} \mathrm{C}$. Cultures were shaken continuously on an orbital shaker (100 rpm). Second-generation EMS mutants were grown under the same conditions. During screening, all Dunaliella strains cultured in the medium were supplemented with $1.5 \mathrm{M} \mathrm{NaCl}$. For salinity optimization of the culture medium, they were cultured in media containing $0.3 \mathrm{M}, 0.6 \mathrm{M}, 1.5$ $\mathrm{M}$, and $3.0 \mathrm{M} \mathrm{NaCl}$, respectively. Experiments of light condition optimization and fed-batch culture were conducted at the optimized salinity, $0.6 \mathrm{M} \mathrm{NaCl}$.

\subsection{Mutagenesis and Mutant Selection}

zea1 cells were harvested in the exponential phase by centrifugation at $840 \times g$ for $5 \mathrm{~min}$. The pelleted cells were re-suspended in the growth medium at a density of $2 \times 10^{8}$ cells $\cdot \mathrm{mL}^{-1}$. The EMS treatment method used was as published previously [22]. Two weeks after spreading on a solid agar medium, colonies that were brighter than zea1 were selected for further analysis of pigment composition.

\subsection{Experimental Culture Conditions}

\subsubsection{Culture Medium Optimization: $\mathrm{NaCl}$ Concentration}

To establish the effects of salinity on growth and xanthophyll pigment production, different $\mathrm{NaCl}$ concentrations $(0.3 \mathrm{M}, 0.6 \mathrm{M}, 1.5 \mathrm{M}$, and $3.0 \mathrm{M})$ were assayed in $200 \mathrm{~mL}$ single-batch cultures in $500 \mathrm{~mL}$ culture flasks. The cells, after adapting to different salinities for 1 week, were inoculated at about $2.5 \times 10^{5}$ cells $\cdot \mathrm{mL}^{-1}$, and were cultured in low-light conditions $\left(65-85 \mu \mathrm{mol}\right.$ photons $\left.\cdot \mathrm{m}^{-2} \cdot \mathrm{s}^{-1}\right)$, with orbital shaking (100 rpm). All experiments were conducted in triplicate. 


\subsubsection{Culture Condition Optimization: Irradiance}

To establish the effects of light intensity on growth and xanthophyll pigment production, three different irradiances were assayed in $200 \mathrm{~mL}$ single-batch cultures in $500 \mathrm{~mL}$ culture flasks: low-light $\left(65-85 \mu \mathrm{mol}\right.$ photons $\left.\cdot \mathrm{m}^{-2} \cdot \mathrm{s}^{-1}\right)$, mid-light $\left(140-160 \mu \mathrm{mol}\right.$ photons $\left.\cdot \mathrm{m}^{-2} \cdot \mathrm{s}^{-1}\right)$, and high-light (580-620 $\mu \mathrm{mol}$ photons $\left.\cdot \mathrm{m}^{-2} \cdot \mathrm{s}^{-1}\right)$. The cells, adapted to different light conditions for 1 week, were inoculated at about $2.5 \times 10^{5}$ cells. $\mathrm{mL}^{-1}$, and were cultured by orbital shaking (100 rpm) on the medium containing $0.6 \mathrm{M} \mathrm{NaCl}$, which was selected for culture medium optimization. All experiments were conducted in more than triplicate.

\subsubsection{Repeated Fed-Batch Culture}

To measure zeaxanthin yield at maximal cell density in flask cultures, the repeated fed-batch culture system was used in pulse-feeding mode with multiple cycles. Cells were adapted to the medium containing $0.6 \mathrm{M} \mathrm{NaCl}$. Thereafter, they were inoculated at about $2.5 \times 10^{5}$ cells $\cdot \mathrm{mL}^{-1}$ in $200 \mathrm{~mL}$ of culture medium in $500 \mathrm{~mL}$ culture flasks, and were cultured under mid-light conditions (140-160 $\mu \mathrm{mol}$ photons $\left.\cdot \mathrm{m}^{-2} \cdot \mathrm{s}^{-1}\right)$, with orbital shaking $(100 \mathrm{rpm})$. When the cells reached the stationary phase, they were harvested by centrifugation at $840 \times g$ for $15 \mathrm{~min}$ and the culture medium was removed. Fresh culture medium was then added to the flask, and a new cultivation cycle was started. These processes were repeated until the cell density no longer increased. All experiments were conducted in triplicate.

\subsection{Analytical Methods}

\subsubsection{Specific Growth Rate and Biomass}

Specific growth rate $(\mu)$ was calculated from the measured cell density, during the exponential phase, using the equation: $\mu=\ln \left(D_{2} / D_{1}\right) /\left(t_{2}-t_{1}\right)$, where $D_{2}$ and $D_{1}$ represent cell density $\left(\times 10^{4}\right.$ cells $\left.\cdot \mathrm{mL}^{-1}\right)$ at times $t_{2}$ and $t_{1}$, respectively [55].

Microalgal biomass was measured as dry weight as described previously [22], with slight modifications: $100 \mathrm{~mL}$ of cell culture was harvested by centrifugation at $1500 \times \mathrm{g}$ for $5 \mathrm{~min}$ at $20{ }^{\circ} \mathrm{C}$. To remove cell-debris, the supernatant (medium) was carefully discarded, and the pellets were washed once. Cells were re-suspended and transferred to a pre-weighed $15 \mathrm{~mL}$ Falcon tube (A). Cells were harvested by centrifugation at $1500 \times g$ for $5 \mathrm{~min}$ at $20^{\circ} \mathrm{C}$, and the supernatant was completely removed. After drying for $24 \mathrm{~h}$ at $65^{\circ} \mathrm{C}$, the tubes were re-weighed (B). Net dry weight was calculated as "(B) - (A)". Biomass was also quantified as cell density by direct cell counting using a hemocytometer (Marienfeld-Superior, Lauda-Königshofen, Germany) in the 25 central squares of the chamber.

\subsubsection{Pigment Analysis}

For pigment extraction, samples were collected early in the stationary phase. Each $0.5 \mathrm{~mL}$ aliquot of cell culture $\left(2.5 \times 10^{6}\right.$ cells $\left.\cdot \mathrm{mL}^{-1}\right)$ was harvested by centrifugation $(20,000 \times g, 2 \mathrm{~min})$, and the supernatant was discarded. Pigments were extracted by pipetting the pellet into $0.5 \mathrm{~mL}$ of $90 \%$ $(w / w)$ acetone for $1 \mathrm{~min}$. After centrifugation at 20,000 $\mathrm{g}$ for $5 \mathrm{~min}$, the supernatant was filtered through a $0.2-\mu \mathrm{m}$ nylon filter. Filtrate was analyzed on a Shimadzu Prominence high-performance liquid chromatography (HPLC) system (model LC-20AD) (Shimadzu, Kyoto, Japan), equipped with a Waters Spherisorb S5 ODS2 cartridge column $(4.6 \times 250 \mathrm{~mm})$ (Waters, MA, USA). HPLC analysis was performed according to the method described by Park et al. [56]. Pigments were identified by retention time and absorption spectra with reference to pigment standards (DHI 14C Centralen; Denmark). Concentrations of individual pigments were determined by HPLC using the same standards. To calculate daily zeaxanthin productivity, the content was divided by the culturing period. 


\section{Conclusions}

The green alga Dunaliella tertiolecta can adapt to diverse saline environments and we consider it an ideal organism for carotenoid pigment production using natural seawater. The strain characterized in this study, D. tertiolecta mutant $m p 3$, accumulated zeaxanthin under all growth conditions. In lab-scale culture, $0.6 \mathrm{M}$ salinity and light intensity of $140-160 \mu \mathrm{mol}$ photons $\cdot \mathrm{m}^{-2} \cdot \mathrm{s}^{-1}$ were selected as optimal conditions for zeaxanthin production. The maximal yield of zeaxanthin was $8 \mathrm{mg} \cdot \mathrm{L}^{-1}$ under these conditions. Our results demonstrate that $D$. tertiolecta mp3 is an interesting and promising marine microalga for zeaxanthin production and commercial applications.

Supplementary Materials: The following are available online at www.mdpi.com/1660-3397/15/6/189/s1, Figure S1: Zeaxanthin content and growth pattern of $D$. tertiolecta strains selected during mutant screening. (A) Zeaxanthin contents of wild type, zea1, and three mutants (based on chlorophyll $a$ ). The mut12 was named as mp3 mutant; (B) Growth pattern of wild type, zea1, and three mutants, Figure S2: Microscopic images of wild type $D$. tertiolecta, zea1 mutant and mp3 mutant. The plastid regions (green) of the wild type and zea1 were larger than that of the mp3 mutant strain, whereas auto-fluorescence signal patterns were similar. Left side, differential interference contrast (DIC) images; right side, auto-fluorescence (AF) images, Figure S3: Zeaxanthin productivity of wild type $D$. tertiolecta, zea1 mutant and mp3 mutant. Experimental light conditions were low-light (LL), mid-light (ML) and high-light (HL). Statistical analyses were performed using Student's $t$-test, ${ }^{*} p<0.05$. All experiments were conducted in more than triplicate, Table S1: Effects of salinity on volumetric and cellular biomass. (A) Volumetric biomass of wild type (WT), zea1 and $m p 3$ mutant $\left(\mathrm{g} \cdot \mathrm{L}^{-1}\right)$; (B) Cellular biomass of wild type (WT), zea1 and mp3 mutant $\left(\mathrm{mg} \cdot 10^{6} \cdot \mathrm{cells}^{-1}\right)$, Table S2: Effects of irradiance on specific growth rates of wild type (WT), zea1 and mp3.

Acknowledgments: This research was supported by a grant from the Korea CCS R\&D Center (KCRC) (NRF-2014M1A8A1049273) funded by the Korean Government (Ministry of Science, Ict. \& Future Planning), the Basic Core Technology Development Program for the Oceans and the Polar Regions of the National Research Foundation (NRF-2015M1A5A1037053), and the Marine Biotechnology Program (PJT200255, Development of Marine Microalgal Biofuel Production Technology) funded by the Ministry of Oceans and Fisheries.

Author Contributions: M.K. and E.J. conceived and designed the experiments. M.K. and J.A. performed the experiments. M.K. and H.J. analyzed the data. M.K. and E.J. wrote the main manuscript text. All authors reviewed the manuscript.

Conflicts of Interest: The authors declare no conflict of interest.

\section{References}

1. Mulders, K.J.; Lamers, P.P.; Martens, D.E.; Wijffels, R.H. Phototrophic pigment production with microalgae: Biological constraints and opportunities. J. Phycol. 2014, 50, 229-242. [CrossRef] [PubMed]

2. Lemoine, Y.; Schoefs, B. Secondary ketocarotenoid astaxanthin biosynthesis in algae: A multifunctional response to stress. Photosynth. Res. 2010, 106, 155-177. [CrossRef] [PubMed]

3. Bernstein, P.S.; Li, B.; Vachali, P.P.; Gorusupudi, A.; Shyam, R.; Henriksen, B.S.; Nolan, J.M. Lutein, zeaxanthin, and meso-zeaxanthin: The basic and clinical science underlying carotenoid-based nutritional interventions against ocular disease. Prog. Retin. Eye Res. 2016, 50, 34-66. [CrossRef] [PubMed]

4. Nwachukwu, I.D.; Udenigwe, C.C.; Aluko, R.E. Lutein and zeaxanthin: Production technology, bioavailability, mechanisms of action, visual function, and health claim status. Trends Food Sci. Technol. 2016, 49, 74-84. [CrossRef]

5. Lin, J.-H.; Lee, D.-J.; Chang, J.-S. Lutein production from biomass: Marigold flowers versus microalgae. Bioresour. Technol. 2015, 184, 421-428. [CrossRef] [PubMed]

6. Sajilata, M.; Singhal, R.; Kamat, M. The carotenoid pigment zeaxanthin-A review. Compr. Rev. Food Sci. Food Saf. 2008, 7, 29-49. [CrossRef]

7. Johnson-Down, L.; Saudny-Unterberger, H.; Gray-Donald, K. Food habits of Canadians: Lutein and lycopene intake in the Canadian population. J. Am. Diet. Assoc. 2002, 102, 988-991. [CrossRef]

8. Hadden, W.L.; Watkins, R.H.; Levy, L.W.; Regalado, E.; Rivadeneira, D.M.; Van Breemen, R.B.; Schwartz, S.J. Carotenoid composition of marigold (Tagetes erecta) flower extract used as nutritional supplement. J. Agric. Food Chem. 1999, 47, 4189-4194. [CrossRef] [PubMed] 
9. Del Campo, J.; Rodriguez, H.; Moreno, J.; Vargas, M.; Rivas, J.; Guerrero, M. Accumulation of astaxanthin and lutein in Chlorella zofingiensis (Chlorophyta). Appl. Microbiol. Biotechnol. 2004, 64, 848-854. [CrossRef] [PubMed]

10. Ho, S.-H.; Chan, M.-C.; Liu, C.-C.; Chen, C.-Y.; Lee, W.-L.; Lee, D.-J.; Chang, J.-S. Enhancing lutein productivity of an indigenous microalga Scenedesmus obliquus FSP-3 using light-related strategies. Bioresour. Technol. 2014, 152, 275-282. [CrossRef] [PubMed]

11. Del Campo, J.A.; Moreno, J.; Rodrìguez, H.; Vargas, M.A.; Rivas, J.; Guerrero, M.G. Carotenoid content of chlorophycean microalgae: Factors determining lutein accumulation in Muriellopsis sp. (Chlorophyta). J. Biotechnol. 2000, 76, 51-59. [CrossRef]

12. Chen, C.-R.; Hong, S.-E.; Wang, Y.-C.; Hsu, S.-L.; Hsiang, D.; Chang, C.-M.J. Preparation of highly pure zeaxanthin particles from sea water-cultivated microalgae using supercritical anti-solvent recrystallization. Bioresour. Technol. 2012, 104, 828-831. [CrossRef] [PubMed]

13. Granado-Lorencio, F.; Herrero-Barbudo, C.; Acién-Fernández, G.; Molina-Grima, E.; Fernández-Sevilla, J.; Pérez-Sacristán, B.; Blanco-Navarro, I. In vitro bioaccesibility of lutein and zeaxanthin from the microalgae Scenedesmus almeriensis. Food Chem. 2009, 114, 747-752. [CrossRef]

14. Chen, F.; Li, H.-B.; Wong, R.N.S.; Ji, B.; Jiang, Y. Isolation and purification of the bioactive carotenoid zeaxanthin from the microalga Microcystis aeruginosa by high-speed counter-current chromatography. J. Chromatogr. A 2005, 1064, 183-186. [CrossRef] [PubMed]

15. Fernández-Sevilla, J.M.; Fernández, F.A.; Grima, E.M. Biotechnological production of lutein and its applications. Appl. Microbiol. Biotechnol. 2010, 86, 27-40. [CrossRef] [PubMed]

16. Manke Natchigal, A.; Oliveira Stringheta, A.; Corrêa Bertoldi, M.; Stringheta, P. Quantification and characterization of lutein from Tagetes (Tagetes patula L.) and Calendula (Calendula officinalis L.) flowers. In Proceedings of the XXVIII International Horticultural Congress on Science and Horticulture for People (IHC2010): International Symposium on Emerging Health Topics in Fruits and Vegetables, Lisborn, Portugal, 22-27 August 2010; pp. 309-314.

17. Ben-Amotz, A.; Avron, M. Photosynthetic activities of the halophilic alga Dunaliella parva. Plant Physiol. 1972, 49, 240-243. [CrossRef] [PubMed]

18. Park, S.; Kim, M.; Lee, S.-G.; Lee, Y.; Choi, H.-K.; Jin, E. Contrasting photoadaptive strategies of two morphologically distinct Dunaliella species under various salinities. J. Appl. Phycol. 2015, 27, 1053-1062. [CrossRef]

19. Borowitzka, M.A.; Borowitzka, L.J.; Kessly, D. Effects of salinity increase on carotenoid accumulation in the green alga Dunaliella salina. J. Appl. Phycol. 1990, 2, 111-119. [CrossRef]

20. Pal, D.; Khozin-Goldberg, I.; Didi-Cohen, S.; Solovchenko, A.; Batushansky, A.; Kaye, Y.; Sikron, N.; Samani, T.; Fait, A.; Boussiba, S. Growth, lipid production and metabolic adjustments in the euryhaline eustigmatophyte Nannochloropsis oceanica CCALA 804 in response to osmotic downshift. Appl. Microbiol. Biotechnol. 2013, 97, 8291-8306. [CrossRef] [PubMed]

21. Aburai, N.; Sumida, D.; Abe, K. Effect of light level and salinity on the composition and accumulation of free and ester-type carotenoids in the aerial microalga Scenedesmus sp. (Chlorophyceae). Algal Res. 2015, 8, 30-36. [CrossRef]

22. Jin, E.; Feth, B.; Melis, A. A mutant of the green alga Dunaliella salina constitutively accumulates zeaxanthin under all growth conditions. Biotechnol. Bioeng. 2003, 81, 115-124. [CrossRef] [PubMed]

23. Jin, E.; Yokthongwattana, K.; Polle, J.E.; Melis, A. Role of the reversible xanthophyll cycle in the photosystem II damage and repair cycle in Dunaliella salina. Plant Physiol. 2003, 132, 352-364. [CrossRef] [PubMed]

24. Thaipratum, R.; Melis, A.; Svasti, J.; Yokthongwattana, K. Analysis of non-photochemical energy dissipating processes in wild type Dunaliella salina (green algae) and in zea1, a mutant constitutively accumulating zeaxanthin. J. Plant Res. 2009, 122, 465-476. [CrossRef] [PubMed]

25. Hieber, A.D.; Bugos, R.C.; Yamamoto, H.Y. Plant lipocalins: Violaxanthin de-epoxidase and zeaxanthin epoxidase. Biochim. Biophys. Acta Protein Struct. Mol. Enzymol. 2000, 1482, 84-91. [CrossRef]

26. Cebollero, E.; Gonzalez-Ramos, D.; Tabera, L.; Gonzalez, R. Transgenic wine yeast technology comes of age: Is it time for transgenic wine? Biotechnol. Lett. 2007, 29, 191-200. [CrossRef] [PubMed]

27. Haughn, G.; Somerville, C. Selection for herbicide resistance at the whole-plant level. In Biotechnology in Agricultural Chemistry; Oxford University Press: Oxford, UK, 1987; pp. 98-107. 
28. Ashburner, M. Drosophila: A Laboratory Handbook; Cold Spring Harbor Laboratory: Englewood Cliffs, NJ, USA, 1989.

29. Pérez-Torrado, R.; Querol, A.; Guillamón, J.M. Genetic improvement of non-GMO wine yeasts: Strategies, advantages and safety. Trends Food Sci. Technol. 2015, 45, 1-11. [CrossRef]

30. Chaturvedi, R.; Fujita, Y. Isolation of enhanced eicosapentaenoic acid producing mutants of Nannochloropsis oculata ST-6 using ethyl methane sulfonate induced mutagenesis techniques and their characterization at mRNA transcript level. Phycol. Res. 2006, 54, 208-219. [CrossRef]

31. Ong, S.-C.; Kao, C.-Y.; Chiu, S.-Y.; Tsai, M.-T.; Lin, C.-S. Characterization of the thermal-tolerant mutants of Chlorella sp. with high growth rate and application in outdoor photobioreactor cultivation. Bioresour. Technol. 2010, 101, 2880-2883. [CrossRef] [PubMed]

32. Anandarajah, K.; Mahendraperumal, G.; Sommerfeld, M.; Hu, Q. Characterization of microalga Nannochloropsis sp. mutants for improved production of biofuels. Appl. Energy 2012, 96, 371-377. [CrossRef]

33. Zhang, Y.; He, M.; Zou, S.; Fei, C.; Yan, Y.; Zheng, S.; Rajper, A.A.; Wang, C. Breeding of high biomass and lipid producing Desmodesmus sp. by Ethylmethane sulfonate-induced mutation. Bioresour. Technol. 2016, 207, 268-275. [CrossRef] [PubMed]

34. Melis, A. Solar energy conversion efficiencies in photosynthesis: Minimizing the chlorophyll antennae to maximize efficiency. Plant Sci. 2009, 177, 272-280. [CrossRef]

35. Jeong, J.; Baek, K.; Kirst, H.; Melis, A.; Jin, E. Loss of CpSRP54 function leads to a truncated light-harvesting antenna size in Chlamydomonas reinhardtii. Biochim. Biophys. Acta Bioenerg. 2017, 1858, 45-55. [CrossRef] [PubMed]

36. Ahrazem, O.; Rubio-Moraga, A.; López, R.C.; Gómez-Gómez, L. The expression of a chromoplast-specific lycopene beta cyclase gene is involved in the high production of saffron's apocarotenoid precursors. J. Exp. Bot. 2010, 61, 105-119. [CrossRef] [PubMed]

37. Davison, P.; Hunter, C.; Horton, P. Overexpression of $\beta$-carotene hydroxylase enhances stress tolerance in Arabidopsis. Nature 2002, 418, 203-206. [CrossRef] [PubMed]

38. Baek, K.; Kim, D.H.; Jeong, J.; Sim, S.J.; Melis, A.; Kim, J.-S.; Jin, E.; Bae, S. DNA-free two-gene knockout in Chlamydomonas reinhardtii via CRISPR-Cas9 ribonucleoproteins. Sci. Rep. 2016, 6, 30620. [CrossRef] [PubMed]

39. Minhas, A.K.; Hodgson, P.; Barrow, C.J.; Adholeya, A. A review on the assessment of stress conditions for simultaneous production of microalgal lipids and carotenoids. Front. Microbiol. 2016, 7, 546. [CrossRef] [PubMed]

40. Kirst, G. Salinity tolerance of eukaryotic marine algae. Annu. Rev. Plant Biol. 1990, 41, 21-53. [CrossRef]

41. Müller, P.; Li, X.-P.; Niyogi, K.K. Non-photochemical quenching. A response to excess light energy. Plant Physiol. 2001, 125, 1558-1566. [CrossRef] [PubMed]

42. Pulz, O. Photobioreactors: Production systems for phototrophic microorganisms. Appl. Microbiol. Biotechnol. 2001, 57, 287-293. [PubMed]

43. Tang, H.; Abunasser, N.; Garcia, M.; Chen, M.; Ng, K.S.; Salley, S.O. Potential of microalgae oil from Dunaliella tertiolecta as a feedstock for biodiesel. Appl. Energy 2011, 88, 3324-3330. [CrossRef]

44. Sharma, Y.C.; Singh, B.; Korstad, J. A critical review on recent methods used for economically viable and eco-friendly development of microalgae as a potential feedstock for synthesis of biodiesel. Green Chem. 2011, 13, 2993-3006. [CrossRef]

45. Cheirsilp, B.; Torpee, S. Enhanced growth and lipid production of microalgae under mixotrophic culture condition: Effect of light intensity, glucose concentration and fed-batch cultivation. Bioresour. Technol. 2012, 110, 510-516. [CrossRef] [PubMed]

46. De Swaaf, M.E.; Sijtsma, L.; Pronk, J.T. High-cell-density fed-batch cultivation of the docosahexaenoic acid producing marine alga Crypthecodinium cohnii. Biotechnol. Bioeng. 2003, 81, 666-672. [CrossRef] [PubMed]

47. Shi, X.M.; Chen, F. High-yield production of lutein by the green microalga Chlorella protothecoidesin heterotrophic fed-batch culture. Biotechnol. Prog. 2002, 18, 723-727. [CrossRef] [PubMed]

48. Moros, E.; Darnoko, D.; Cheryan, M.; Perkins, E.; Jerrell, J. Analysis of xanthophylls in corn by HPLC. J. Agric. Food Chem. 2002, 50, 5787-5790. [CrossRef] [PubMed]

49. Zhou, L.; Leung, I.; Tso, M.O.; Lam, K.-W. The identification of dipalmityl zeaxanthin as the major carotenoid in Gou Qi Zi by high pressure liquid chromatography and mass spectrometry. J. Ocul. Pharmacol. Ther. 1999, 15, 557-565. [CrossRef] [PubMed] 
50. Cordero, B.F.; Obraztsova, I.; Couso, I.; Leon, R.; Vargas, M.A.; Rodriguez, H. Enhancement of lutein production in Chlorella sorokiniana (Chorophyta) by improvement of culture conditions and random mutagenesis. Mar. Drugs 2011, 9, 1607-1624. [CrossRef] [PubMed]

51. Römer, S.; Lübeck, J.; Kauder, F.; Steiger, S.; Adomat, C.; Sandmann, G. Genetic engineering of a zeaxanthin-rich potato by antisense inactivation and co-suppression of carotenoid epoxidation. Metab. Eng. 2002, 4, 263-272. [CrossRef] [PubMed]

52. Park, S.; Polle, J.E.; Melis, A.; Lee, T.K.; Jin, E. Up-regulation of photoprotection and PSII-repair gene expression by irradiance in the unicellular green alga Dunaliella salina. Mar. Biotechnol. 2006, 8, 120-128. [CrossRef] [PubMed]

53. Kim, M.; Park, S.; Polle, J.E.; Jin, E. Gene expression profiling of Dunaliella sp. acclimated to different salinities. Phycol. Res. 2010, 58, 17-28. [CrossRef]

54. Pick, U.; Karni, L.; Avron, M. Determination of ion content and ion fluxes in the halotolerant alga Dunaliella salina. Plant Physiol. 1986, 81, 92-96. [CrossRef] [PubMed]

55. Levasseur, M.; Thompson, P.A.; Harrison, P.J. Physiological acclimation of marine phytoplankton to different nitrogen sources. J. Phycol. 1993, 29, 587-595. [CrossRef]

56. Park, S.; Jung, G.; Hwang, Y.-S.; Jin, E. Dynamic response of the transcriptome of a psychrophilic diatom, Chaetoceros neogracile, to high irradiance. Planta 2010, 231, 349-360. [CrossRef] [PubMed]

(C) 2017 by the authors. Licensee MDPI, Basel, Switzerland. This article is an open access article distributed under the terms and conditions of the Creative Commons Attribution (CC BY) license (http://creativecommons.org/licenses/by/4.0/). 